Available online at GSC Online Press Directory

GSC Biological and Pharmaceutical Sciences

e-ISSN: 2581-3250, CODEN (USA): GBPSC2

Journal homepage: https://www.gsconlinepress.com/journals/gscbps

(RESEARCH ARTICLE)

\title{
Cucumber (Cucumis sativus) and tomato (Solanum lycopersicum) juice effective to
} reduce blood pressure

\author{
Siti Fadlilah *, Adi Sucipto and Mohamad Judha \\ Department of Medical and Surgical Nursing, Universitas Respati Yogyakarta, Indonesia.
}

Publication history: Received on 18 December 2019; revised on 06 January 2020; accepted on 09 January 2020

Article DOI: https://doi.org/10.30574/gscbps.2020.10.1.0246

\begin{abstract}
The fruits contain potassium, magnesium, phosphorus and lycopene can maintain blood pressure. This study aims to determine the effectiveness of cucumber and tomato juice on blood pressure. This study was a quasi-experimental with a pre-posttest design without control. The sampling used quota sampling was 36 respondents, divided into cucumber juice group was 18 respondents, and tomato juice group was 18 respondents. The research instrument used observation sheets and digital sphygmomanometers. Each group received juice every day in 7 days. Statistical tests using ShapiroWilk. The mean pre-posttest systolic and diastolic blood pressure in the cucumber juice group was 115.50-115.39 $\mathrm{mmHg}$ and 79.39-77.28 mmHg. The mean pre-posttest systolic and diastolic blood pressure in the tomato juice group was 110.67-109.78 $\mathrm{mmHg}$ and 77.39-73.61 mmHg. P-value pre-posttest systolic and diastolic blood pressure in cucumber juice group were 0.000 and 0.000 . P-value pre-posttest systolic and diastolic blood pressure in tomato juice group were 0.000 and 0.000 . P-value of the posttest systolic and diastolic blood pressure tests among two groups were 0.734 and 0.674 . Giving cucumber juice and tomato juice is effective in helping to reduce systolic and diastolic blood pressure. There is no difference in effectiveness between cucumber juice and tomato juice.
\end{abstract}

Keywords: Cucumber; Tomato; Blood Pressure

\section{Introduction}

Blood pressure is a very important factor in the circulatory system. There are two types of blood pressure abnormalities, namely hypertension or high blood pressure and hypotension or low blood pressure. Hypertension is a condition where blood pressure is more than $140 / 90 \mathrm{mmHg}$. While hypotension is a condition where blood pressure is lower than $90 / 60$ $\mathrm{mmHg}$ or blood pressure is low enough to cause symptoms such as dizziness and fainting [1].

World Health Organization (WHO) explained that hypertension is one of the factors of global death and is estimated to have caused 9.4 million deaths in 2010. Hypertension is estimated to contribute $12.8 \%$ of deaths worldwide. The prevalence of hypertension is highest in Africa (46\%) and lowest in America (35\%). High-income countries have lower prevalence compared to low-income countries [2]. Although orthostatic hypotension can occur in all age groups, it is reported more often in older adults, especially those who are sick. In the United States, orthostatic hypotension is $30 \%$ of older adults and up to 70\% of residents of nursing homes. The incidence of orthostatic hypotension occurs in 47-58\% of patients with Parkinson's disease, $13-32 \%$ of those with hypertension, $16-25 \%$ of those with diabetes mellitus and $24 \%$ of those with carotid artery stenosis [3].

The prevalence of hypertension in Indonesia continues to increase in number. In 2007, the prevalence of hypertension was $7.6 \%$ and increased to $9.5 \%$ in 2013 . The number of hypertension sufferers in Yogyakarta is the third highest after

\footnotetext{
${ }^{*}$ Corresponding author

E-mail address: sitifadlilah@respati.ac.id
} 
East Nusa Tenggara and South Kalimantan [4]. While, the prevalence of hypotension is generally estimated to be $5 \%$ to $34 \%$ and usually increases at the age of 17-19 years [3].

Some ways in managing blood pressure are maintaining ideal body weight, reducing sodium (sodium intake), limiting alcohol consumption, eating enough $\mathrm{K}$ and Ca sources from the diet, avoiding smoking, reducing stress, and therapeutic massage. Management of blood pressure disorders is pursued by non-pharmacological. The non-pharmacological treatment uses traditional plants or fruits [5]. One way to control blood pressure is to be able to consume cucumber juice and tomato juice. Consuming cucumbers can reduce blood pressure and is very good for people with hypertension, containing potassium which is the primary intracellular electrolyte. Cucumbers also have a diuretic nature due to their high water content which helps reduce blood pressure [6].

In addition to cucumbers, tomatoes are perfect for hypertension sufferers because they contain potassium and lycopene. The content of potassium and lycopene in tomatoes can reduce blood pressure by inhibiting the release of renin increasing the excretion of sodium and water while lycopene is the most potent antioxidant among other antioxidants. Lycopene also plays a role in reducing LDL and as an anti-atherosclerosis by protecting endothelial vessels from damage, reducing the inflammatory response, and inhibiting the proliferation of smooth muscle cells [7]. Lycopene content in tomatoes which is the highest antioxidant can prevent lipid oxidation from preventing cardiovascular diseases such as hypertension [8]. Cucumber and tomatoes have good prices and are easy to get in everyday life. During this study, the researchers aimed to determine the effectiveness of non-pharmacological treatment using cucumber and tomato juice on blood pressure.

\section{Material and methods}

\subsection{Study Design}

This research was a quasi-experimental study with pretest-posttest without control. Respondents were divided into two groups that were equally treated, namely given cucumber juice and tomato juice (figure 1).

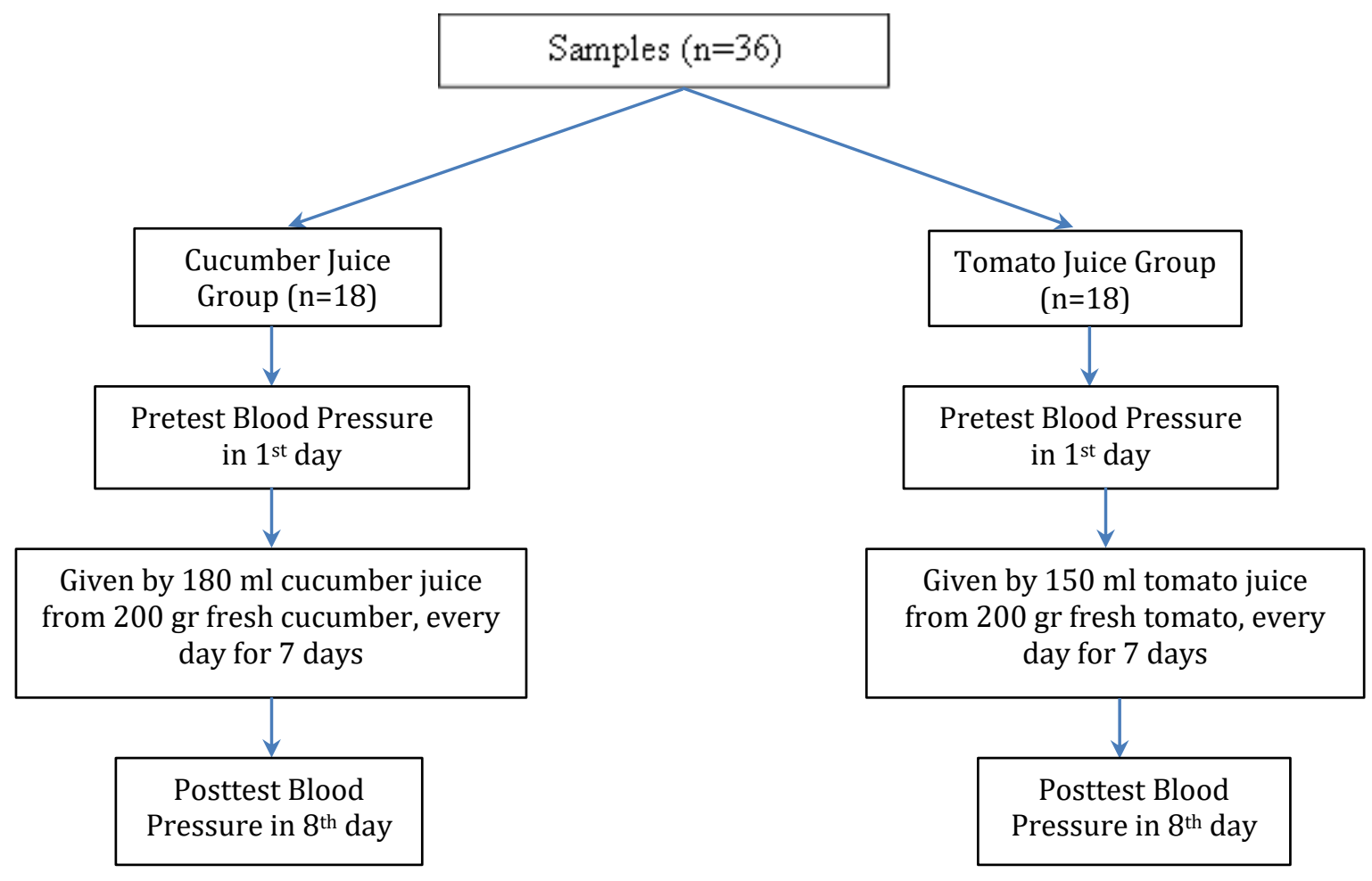

Figure 1 Study framework

\subsection{Participants in the study}

The populations were 138 students of Nutrition Sciences Program at Universitas Respati Yogyakarta. The samples were students who fit the inclusion and exclusion criteria. Inclusion criteria were willing to become a respondent by signing 
informed consent, age 19-23 years old, normal body mass index, not taking blood pressure medication, not smoking, and not consuming alcohol. Exclusion criteria were allergic to consume cucumbers and tomatoes, had a history of gastritis, and a condition of pain. The sample can be calculated using the formula:

$(\mathrm{t}-1)(\mathrm{r}-1)=15$

which $\mathrm{t}=$ many treatment groups and $\mathrm{r}=$ number of replications.

The calculation results obtained a sample of 16 people plus the anticipation of drop out of $10 \%$ so that the number of samples becomes 18 groups. The research site was conducted on April 26-May 3, 2019. The sampling technique used in this study was using the method of Quota Sampling.

\subsection{Instruments}

Cucumber and tomato juice were made using a juicer by standard operating procedures that have been made previously. Blood pressure was measured using a digital sphygmomanometer Omron brand. Blood pressure measurements were by standard operational procedures. The measurement results were recorded on the observation sheet.
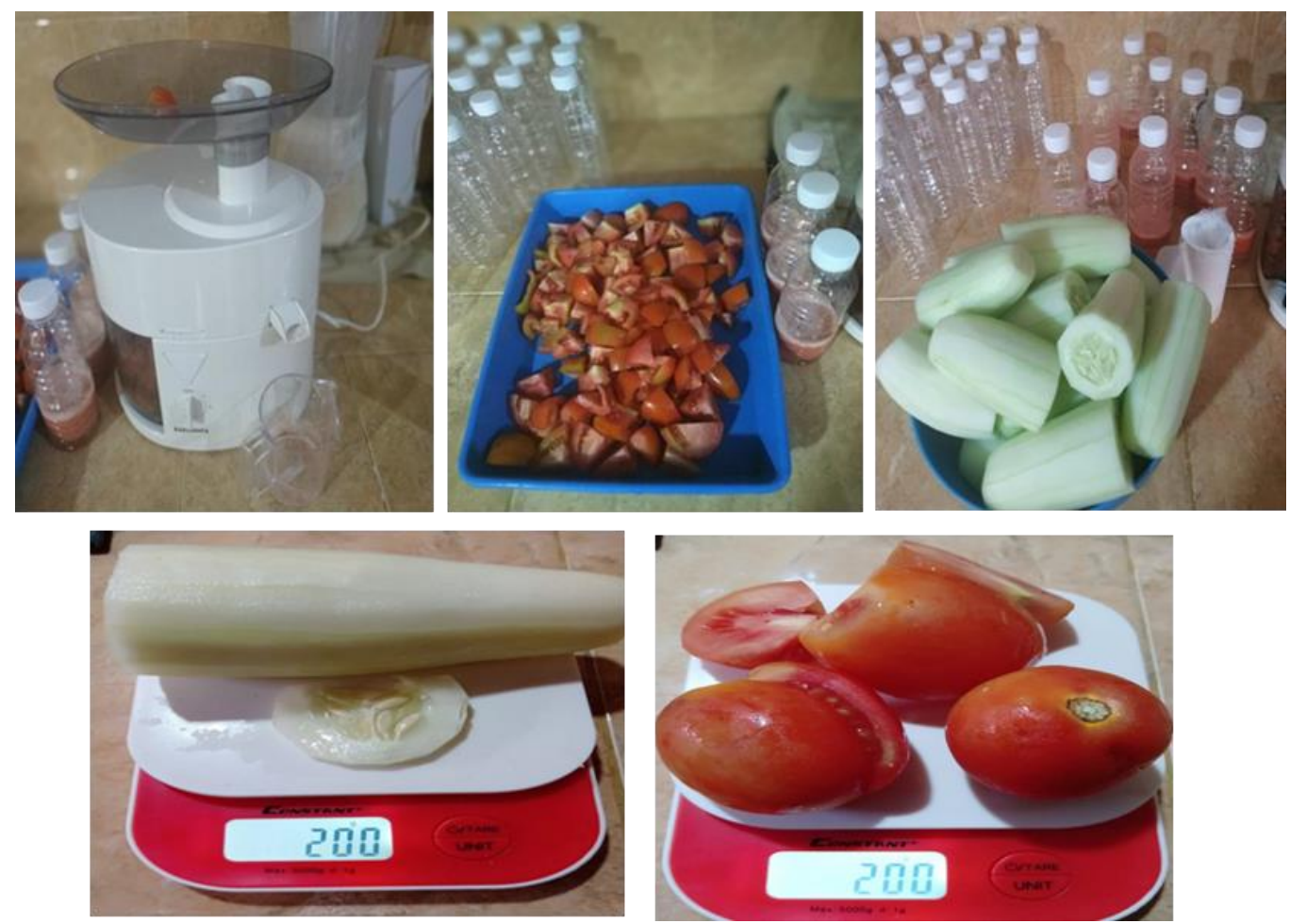

Figure 2 Instruments

\subsection{Intervention and data collection}

The first group received an intervention in the form of giving cucumber juice. Cucumber juice was made from 200 grams of cucumber that has been cleaned and then mashed using a juicer obtained $180 \mathrm{ml}$ of cucumber juice. The juice was given once a day in the morning (07.00-09.00 am) for seven consecutive days. The second group got tomato juice. Tomato juice was made from 200 grams of tomatoes that have been cleaned and then mashed using a juicer obtained $150 \mathrm{ml}$ of tomato juice. The juice was given once a day in the morning (07.00-09.00 am) for seven consecutive days. Samples were measured blood pressure at pretest and posttest. Blood pressure was measured in the left arm, in a sitting position after resting for 5 minutes. Pretest blood pressure was measured on the first day before being given cucumber juice and tomato juice. Posted blood pressure was measured on the eighth day (one day after treatment was completed) at 07.00-09.00 am. 

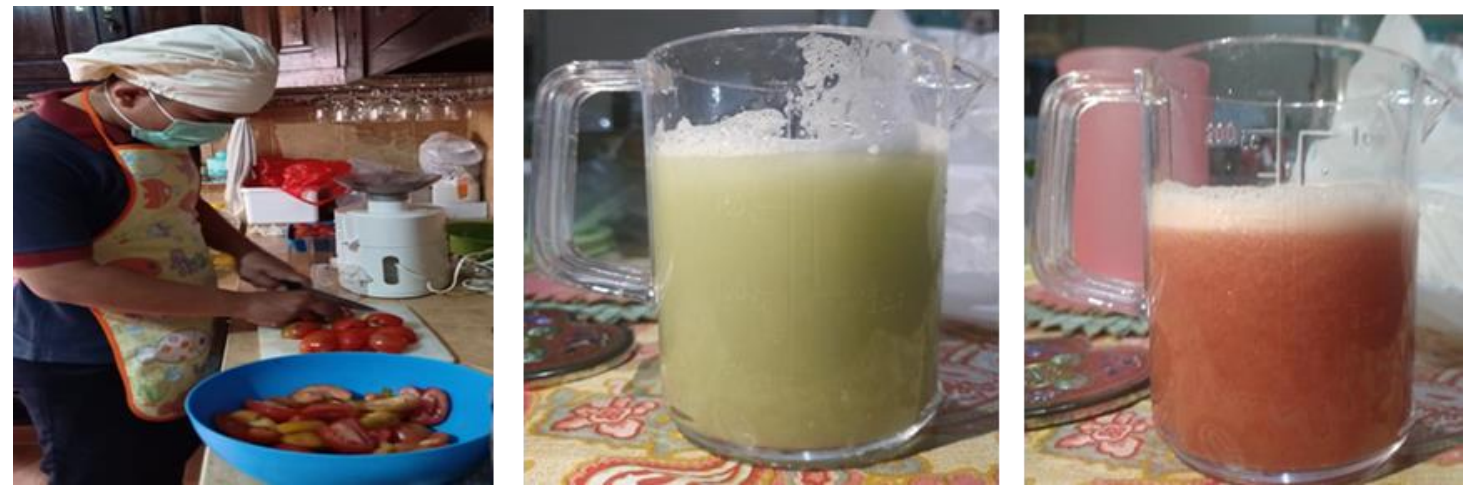

Figure 3 Juice Preparation

\subsection{Data analysis}

This study used normality test with the Shapiro Wilk test. The result of normality data, pretest-posttest of systolic blood pressure among cucumber/tomato groups were 0.054 and $0.501 / 0.675$ and 0.432 . The pretest-posttest of diastolic blood pressure among cucumber/tomato groups were 0.491 and $0.945 / 0.056$ and 0.092 . The normality test results of cucumber juice and tomato juice were generally distributed so that the statistical tests used in this study were Paired T-Test and Independent T-Test.

\subsection{Ethical consideration}

The study permission obtained from the Head of the Nutrition Science Programme of Universitas Respati Yogyakarta. Informed consent was signed to all respondents before the data collection.

\section{Results}

\subsection{Characteristics of respondents}

Table 1 Characteristics of respondents

\begin{tabular}{lllll}
\hline \multirow{2}{*}{ Category } & \multicolumn{2}{c}{ Cucumber juice group } & \multicolumn{2}{c}{ Tomato juice group } \\
\cline { 2 - 5 } & $\mathrm{f}$ & $\%$ & $\mathrm{f}$ & $\%$ \\
\hline Age (year) & & & & \\
\hline 21 & 16 & 88.9 & 16 & 88.9 \\
22 & 2 & 11.1 & 2 & 11.1 \\
\hline Total & 18 & 100.0 & 18 & 100.0 \\
\hline Gender & & & & \\
Female & 15 & 88.3 & 17 & 94.4 \\
Male & 3 & 11.7 & 1 & 5.6 \\
\hline Total & 18 & 100.0 & 18 & 100.0 \\
\hline
\end{tabular}

Table 1 known that the majority of respondents in both groups were 22 years old, as many as 16 people (88.9\%). In the group of cucumber juice and tomato juice, the majority were female, namely 15 people (88.3\%) and 17 people (94.4\%).

\subsection{Pretest and posttest blood pressure}


Table 2 shows that the mean systolic and diastolic pretest-posttest blood pressure in both groups decreased. In the cucumber juice group, the mean systolic blood pressure decreased from $115.50 \mathrm{mmHg}$ to $111.39 \mathrm{mmHg}$. In diastolic blood pressure, decreased from $79.39 \mathrm{mmHg}$ to $77.28 \mathrm{mmHg}$. In the tomato juice group showed similar results, the mean systolic pressure decreased from $110.67 \mathrm{mmHg}$ to $109.78 \mathrm{mmHg}$. While the mean diastolic pressure decreased from $77.39 \mathrm{mmHg}$ to $73.61 \mathrm{mmHg}$.

Table 2 Systolic blood pressure and diastole cucumber juice

\begin{tabular}{lllll}
\hline \multirow{2}{*}{ Groups groups } & \multicolumn{4}{l}{ Pretest-posttest blood pressure (mmHg) } \\
\cline { 2 - 5 } & Minimum & Maximum & Mean & SD* \\
\hline Cucumber juice & & & \\
Systolic & $90-102$ & $131-120$ & $115.50-111.39$ & $13.161-5.304$ \\
Diastolic & $52-63$ & $97-91$ & $79.39-77.28$ & $10.749-6.875$ \\
\hline Tomato juice & & & \\
Systolic & $90-91$ & $134-131$ & $110.67-109.78$ & $11.616-8.055$ \\
Diastolic & $52-66$ & $88-87$ & $77.39-73.61$ & $9.543-6.705$ \\
\hline
\end{tabular}

\subsection{Effects of cucumber and tomato juice to blood pressure}

Table 3 Effect of cucumber juice and tomato juice on blood pressure

\begin{tabular}{|c|c|c|c|}
\hline \multirow{2}{*}{ Group } & \multicolumn{2}{|c|}{ Blood pressure (mmHg) } & \multirow{2}{*}{ p-value } \\
\hline & Mean & Difference Mean & \\
\hline \multicolumn{4}{|c|}{ Cucumber juice } \\
\hline \multicolumn{4}{|l|}{ Systole } \\
\hline Pretest & 115.50 & -4.11 & $0.000^{*}$ \\
\hline Posttest & 111.39 & & \\
\hline \multicolumn{4}{|l|}{ Diastole } \\
\hline Pretest & 79.39 & -2.11 & $0.000^{*}$ \\
\hline Posttest & 77.28 & & \\
\hline \multicolumn{4}{|c|}{ Tomato juice } \\
\hline \multicolumn{4}{|l|}{ Systole } \\
\hline Pretest & 110.67 & -0.89 & $0.000^{*}$ \\
\hline Posttest & 109.78 & & \\
\hline \multicolumn{4}{|l|}{ Diastole } \\
\hline Pretest & 77.39 & -3.78 & $0.000^{*}$ \\
\hline Posttest & 73.61 & & \\
\hline
\end{tabular}

Table 3 shows that the group of cucumber juice and tomato juice, mean systolic blood pressure pretest-posttest decreased by $4.11 \mathrm{mmHg}$ and $0.89 \mathrm{mmHg}$. The mean of diastolic blood pressure pretest-posttest in the cucumber and tomato juice groups decreased by $2.11 \mathrm{mmHg}$ and $3.78 \mathrm{mmHg}$. The results of the paired t-test for systolic and diastolic blood pressure in both groups showed a p-value of 0.000 , meaning cucumber juice and tomato juice was effective in reducing systolic and diastolic blood pressure in college students. 
Siti et al. / GSC Biological and Pharmaceutical Sciences, 2020, 10(01), 001-008

Table 4 Differences in effectiveness of cucumber juice and tomato juice on systolic and diastolic blood pressure

\begin{tabular}{llll}
\hline Blood pressure & Difference in mean & Difference among group & P-value \\
\hline $\begin{array}{l}\text { Systole } \\
\text { Cucumber juice }\end{array}$ & 4.11 & & \\
$\begin{array}{l}\text { Tomato juice } \\
\text { Diastole }\end{array}$ & 0.89 & 3.22 & $0.734^{*}$ \\
$\begin{array}{l}\text { Cucumber juice } \\
\text { Tomato juice }\end{array}$ & 2.11 & & \\
\hline & 3.78 & 1.67 & $0.674^{*}$ \\
\hline
\end{tabular}

Table 4 shows the difference in systole blood pressure between the cucumber juice and tomato juice group was 3.22 $\mathrm{mmHg}$ and the cucumber juice group showed a decrease in systolic blood pressure more than tomato juice. While the difference in diastolic blood pressure reduction between the two groups was $1.67 \mathrm{mmHg}$, the tomato juice group showed a decrease in diastole blood pressure more than cucumber juice. The results of the independent T-Test on systolic and diastolic blood pressure between the two groups obtained p-values of 0.734 and 0.674 , meaning that there was no significant difference between cucumber juice and tomato juice in reducing the blood pressure of systolic and diastolic in college students.

\section{Discussion}

Classification of blood pressure for adults, namely hypotension, is a state of systolic arterial pressure $<90 \mathrm{mmHg}$, or diastolic pressure $<60 \mathrm{mmHg}$. Normal systolic blood pressure $<120 \mathrm{mmHg}$ and diastolic $<80 \mathrm{mmHg}$, prehypertension systolic blood pressure 120-139 $\mathrm{mmHg}$ and diastolic $80-90 \mathrm{mmHg}$, first-degree hypertension systolic blood pressure 140-159 $\mathrm{mmHg}$ and diastolic 90-99 $\mathrm{mmHg}$, second-degree hypertension systolic blood pressure $\geq 160 \mathrm{mmHg}$ and diastolic $\geq 100 \mathrm{mmHg}$ [9]. Based on table 2, the majority of respondents are included in the normal category. However, the maximum value of systolic blood pressure in the pretest cucumber juice group and the pretest-posttest tomato juice group is in the category of prehypertension.

Table 3 shows that the average blood pressure has decreased. Statistically shows the influence of cucumber juice on blood pressure $(\mathrm{p}=0.000)$. The results of this study indicate the influence of cucumber juice administration on blood pressure in patients with hypertension. Based on the results of research conducted by previous researchers, there was a significant effect of cucumber juice on systolic and diastolic blood pressure [10], [11], [12]. Cucumber (Cucumis sativus L.) can help lower blood pressure. Cucumber juice contains Calories, Carbohydrates, Water, Protein, Sugar, Fiber, Fat, Vitamin C, Vitamin K, Vitamin B1 (Thiamine), Vitamin B2 (Riboflavin), Vitamin B3 (Niacin), Vitamin B5 (Panthothenic acid), Vitamin B9 (Folate), Calcium, Iron, Magnesium, Phosphorus, Kalium (Potassium), Sodium, and Zinc [13].

Cucumber juice is effective in reducing systolic and diastolic blood pressure in respondents. Empirically there is a significant effect of giving cucumber juice on a decrease in blood pressure; this is possible because cucumbers contain kalium (potassium), magnesium, and phosphorus, where these minerals can effectively reduce blood pressure [14]. Potassium plays a role in maintaining the electrolyte stability of the body through the potassium-sodium pump. Potassium content in cucumber juice affects blood vessels; potassium has a natriuretic effect by inhibiting the release of renin-angiotensin, which can increase the excretion of sodium in water. This decrease in sodium excretion causes a decrease in plasma volume, cardiac output, and external pressure, so that blood pressure drops [15].

Based on Table 3 in the tomato juice group, the mean of systole and diastolic blood pressure decreased. Tomatoes (Gycopersicum esculentum mill) combine solanine alkaloids (0.007\%), saponins, folic acid, malic acid, citric acid, bioflavonoids, proteins, fats, sugars (glucose, fructose), trigonous, choline, tomatoes, minerals ( $\mathrm{Ca}, \mathrm{Mg}, \mathrm{P}, \mathrm{K}, \mathrm{Na}, \mathrm{Fe}$, Sulfur, chlorine), vitamins (B1, B2, B6, C, E, Lycopene, Niacin), Potassium, fibre, protein and histamine. Lycopene is a beta carotene yellow pigment in tomatoes, and solanine is efficacious as an antibiotic. It can reduce blood pressure by reducing sodium in urine and water in the same way as diuretics [13].

Potassium in tomato juice can reduce blood pressure by inhibiting the release of renin, resulting in increased excretion of sodium and water. Renin circulates in the blood and works by catalyzing the breakdown of angiotensin to angiotensin I. Angiotensin I changes its active form, angiotensin II with the help of Angiotensin-Converting Enzyme (ACE). 
Angiotensin II has great potential to increase blood pressure; vasoconstrictor and can stimulate aldosterone secretion. Aldosterone increases blood pressure by sodium retention. Sodium and water retention is reduced in the presence of potassium, resulting in a decrease in plasma volume, cardiac output, peripheral pressure, and blood pressure [16]. These results are supported by previous studies which showed that increasing potassium consumption around 2100 $\mathrm{mg}$ (54 mmol) a day could reduce systolic [17], [18], [19].

Table 4 results of the Independent T-Test of systolic pressure and diastole pretest-posttest in the two groups showed that there was no difference in effectiveness between cucumber juice and tomato juice on blood pressure reduction $(p=0.734$ and $p=0.674)$. This shows that cucumber juice and tomato juice are equally effective against reducing blood pressure, and there is no difference between the two. After being given cucumber juice and tomato juice, there was a decrease in blood pressure. Table 4 also shows that in the cucumber juice, the mean difference in systolic blood pressure was higher than $3.32 \mathrm{mmHg}$ compared with tomato juice. That means cucumber juice more reduced systolic blood pressure. While, the mean difference in diastolic blood pressure of the tomato juice group was $1.67 \mathrm{mmHg}$ greater than cucumber juice. That means tomato juice more reduced diastolic blood pressure.

\section{Conclusion}

The results showed that the presence of cucumber juice and tomato juice is effective in reducing blood pressure, both systole and diastole. While between the two fruits, there is no difference in effectiveness in lowering blood pressure, between the two having the same results in lowering blood pressure, no one is better than the other. Both of these fruits are easily found in daily life. Based on the finding of the study, cucumber juice and tomato juice are expected to be used as a basis for non-pharmacological therapy for patients with hypertension. Further researchers are advised to continue the study in respondents with hypertension.

\section{Compliance with ethical standards}

\section{Acknowledgments}

In data collection for this research, we acknowledge the assistances Mohamad Fadly and Adi Yusuf, students of Nursing Science Programme Study; Dela Rizky Anggraini, student of Nutrition Science Programme, Universitas Respati Yogyakarta. This work was supported by Universitas Respati Yogyakarta in 2019.

\section{Disclosure of conflict of interest}

There was no conflict of interest in this study.

\section{Statement of informed consent}

Informed consent was signed to all respondents before the data collection.

\section{References}

[1] VII J. (2003). Express The Seventh Report of the Joint National Committee on Prevention, Detection, Evaluation, and Treatment of High Blood Pressure. United States: NIH Publication.

[2] WHO. (2013). A Global on Hypertension: Silent Killer. Global Health Crisis.

[3] Sriminanda L, Dewi AP and Indriati G. (2014). Effectiveness of Tomato Juice Giving Against Blood Pressure in Patients with Hypotension.

[4] Depkes. (2013). Basic Health Research. Jakarta: Ministry of Health of the Republic of Indonesia.

[5] Mangoting, D. et al. (2008). Herbs with medicinal plants. Jakarta: Self-help Spreaders.

[6] Agency D and FC. (2010). Latest Scientific Data Series Cucumis sativus L. Jakarta: Indonesian National Drug and Food Control Agency.

[7] Ilma W. (2015). Effect of cucumber and tomato juice administration on the blood pressure of women overweight and obese. Journal of Nutrition College, 4(2), 281-287.

[8] Anne A. (2012). Benefits of Tomato Juice. 
[9] JNC_7. (2004). Express The Eighth Report of the Joint National Committee on Prevention, Detection, Evaluation, and Treatment of High Blood Pressure. Amerika Serikat: NIH Publication.

[10] Prakoso A, Feri AMM and Sonhaji S. (2014). Effect of Giving Cucumber Juice on Blood Pressure in the Elderly with Hypertension in Posyandu in Demak Regency. Proceedings of the National and International Seminar at the University of Muhammadiyah Semarang. Semarang.

[11] Probosari E and A. (2014). Effect of Giving Cucumber Juice (Cucumis Sativus L) on Reducing Blood Pressure in Patients with Hypertension in Women Age 40-60 Years. Journal of Nutrition College, 3(4), 818-823.

[12] Ponggohong CE, Sefty R and Amatus Y. (2015). The Effect of Cucumber Juice on Blood Pressure on Hypertension Patients in Tolombukan Village, Kec. Pasan Kab. Southeast Minahasa, 2015. Nursing Journal, 3(2), 1-10.

[13] Herbie T. (2015). Book of Medicinal Plants. Jakarta: Octopus Publishing House.

[14] Barus M, Agustaria G and Agnes J. (2019). Cucumber Juice Therapy Lowers Blood Pressure in Patients with Hypertension. Journal of Mutiara Ners, 2(2), 230-237.

[15] Sherwood L. (2002). Human Physiology From Cells to Systems (8th ed.). Jakarta: EGC.

[16] Smeltzer SC, Bare BG, Hinkle JL and Cheever K. (2013). Brunner \& Suddarth's Textbook of Medical-Surgical Nursing. Twelfth Edition. Jakarta: EGC.

[17] Ria M. (2017). Effects of Giving Tomato Juice on Blood Pressure in Menopausal Women with Hypertension in Kantil Posyandu. Journal of Health Science and Prevention, 1(1), 52-57.

[18] Puruhita PR and N. (2015). Effect of Giving Tomato Juice ( Lycopersicum Commune ) on Systolic Blood Pressure and Diastole in Hypertensive Men Age 40-45 years. Semarang: Diponegoro University Semarang.

[19] Wahyuni and Suryani EF. (2017). Effect of Tomato Fruit Juice Therapy on Reducing Blood Pressure in Patients with Stage 1 Primary Hypertension in Monggot Village, Geyer District, Grobogan Regency. Magelang: Muhamadiyah University.

\section{How to cite this article}

Fadlilah S, Adi S and Mohamad J. (2020). Cucumber (Cucumis sativus) and tomato (Solanum lycopersicum) juice effective to reduce blood pressure. GSC Biological and Pharmaceutical Sciences, 10(1), 01-08. 